INTERLEUKIN-6 (IL-6) is a multifunctional cytokine that regulates the immune response, acute phase anaphylactic reaction, and haematopoiesis. Lipopolysaccharide $(6-24 \mu \mathrm{g} / \mathrm{ml})$ significantly induced $\mathrm{IL}-6$ release from murine spleen cells. In cultured rabbit synovial cells interleukin-1 (IL-1, 1-10 U/ml) induced IL-6 production in a concentration-dependent manner. Triazolodiazepine (Tri) is a hetrazepine platelet-activating factor antagonist. In this study we found that Tri $(0.1-10 \mu \mathrm{mol} / \mathrm{l})$ exerted strong inhibitory effects on LPS stimulated II-6 production in murine spleen cells. Kinetic studies showed that the inhibition of $\mathrm{IL}-6$ release was time-independent. In rabbit synovial cells Tri also reduced IL-6 release induced by $\mathrm{IL}-1$ and tumour necrosis factor. Inhibition of cytokine production by Tri may partially explain its wide and strong anti-inflammatory effects.

Key words: IL-6, Spleen cells, Synovial cells, Triazolodiazepine

\section{Effects of triazolodiazepine on the production of interleukin- 6 from murine spleen cells and rabbit synovial cells in vitro}

\author{
Dian-Wen Ju, ${ }^{1, C A}$ Qin-Yue Zheng, ${ }^{2}$ \\ Xue-Tao Cao, ${ }^{1}$ Qing-Hua Zheng, \\ Xiao-Jun Guan' and Hong-Bin Wang ${ }^{2}$
}

\begin{abstract}
'Department of Immunology, School of Basic Medicine, and ${ }^{2}$ Department of Pharmacology, School of Pharmacy, Second Military Medical University, Shanghai 200433, Peoples' Republic of China
\end{abstract}

CA Corresponding Author

\section{Introduction}

Interleukin-6 (IL-6) is a multifunctional cytokine that regulates the immune response, acute phase anaphylactic reaction, and haematopoiesis. ${ }^{1}$ It is known that IL- 6 is produced by various cells. ${ }^{2}$ Considering that IL- 6 production may play a critical role in a number of disease, chronic inflammation, and lymphoid malignancies, relatively little is known about the effects of anti-inflammatory drugs on cytokine synthesis. It might therefore be worthwhile investigating the relationship between its inhibition and the mechanism of action of anti-inflammatory drugs. Triazolodiazepine (Tri) is a hetrazepine platelet-activating factor (PAF) antagonist. It exerts strong anti-inflammatory effects on many in vivo and in vitro models. ${ }^{3}$ In the present study, the effects of Tri on the production of IL- 6 from mouse splenocytes and cultured rabbit synovial cells were examined.

\section{Materials and Methods}

Animals and chemicals: ICR mice weighing 16-24 g and New Zealand rabbits weighing 1.5-2.5 kg were purchased from the Zoological Experiment Center of the Second Military Medical University. RPMI1640, MEM media and lipopolysaccharide (LPS, Escherichia coli, 055:B5) were purchased from Sigma Chemical Co., USA. Foetal calf serum (FCS) was supplied by the Department of Pathology, Second Mili- tary Medical University. Triazolodiazepine (Tri, WEB 2086) was a kind gift from Boehringer Ingelheim Co., Germany. [ $\left.{ }^{3} \mathrm{H}\right]-\mathrm{TdR}(814 \mathrm{TBq} / \mathrm{mol})$ was obtained from Shanghai Institute of Nuclear Research, Chinese Academy of Sciences. Recombinant human tumour necrosis factor (TNF) was generously provided by Dr Y. Sohmura, Dainippon Pharmaceutical Co., Japan.

Spleen cell preparation and IL-6 induction: Splenocytes were prepared from spleens removed under sterile conditions from sacrificed ICR mice. ${ }^{4}$ The cells were suspended in RPMI-1640 containing penicillin $100 \mathrm{U} / \mathrm{ml}$, streptomycin $100 \mu \mathrm{g} / \mathrm{ml}$, 2mercaptoethanol $50 \mathrm{mmol} / 1$ and 10\% FCS. The cells were cultured in sterile 24-well tissue culture plates (Corning, USA) at a density of $5 \times 10^{6}$ cells $/ \mathrm{ml} /$ well with LPS alone or in combination with different concentrations of Tri. After $48 \mathrm{~h}$ incubation at $37^{\circ} \mathrm{C}$ in a $5 \% \quad \mathrm{CO}_{2}$, humidified atmosphere, the supernatants were collected by centrifugation and stored $-20^{\circ} \mathrm{C}$ until testing for IL- 6 activity.

IL-6 production from rabbit synovial cells in culture: Rabbit synovial cells were cultured according to Ju. ${ }^{5}$ Briefly, synovial membrane tissue was obtained aseptically from the knees of normal adult New Zealand rabbits. The membrane was cut into pieces and stuck to a culture flask with the inner side towards the flask wall. MEM medium supplemented with $10 \%$ FCS, penicillin (100 U/mol) and streptomy- 
cin $(100 \mu \mathrm{g} / \mathrm{ml})$ were added to the flask and cultivation was carried out at $37^{\circ} \mathrm{C}$. When the cells had grown to confluence, they were trypsinized and seeded into a 24 -well plate. Twenty-four hours later, the compounds to be tested were added to the cell monolayer. After $24 \mathrm{~h}$ incubation the supernatants were collected by centrifugation and stored at $-20^{\circ} \mathrm{C}$ for IL-6 assay.

IL-6 bioassay: To measure IL-6 activity in the supernatants, the murine IL-6 dependent hybridoma cell line 7TD1 was used. ${ }^{6}$ Briefly, cells were cultured on culture flasks in RPMI-1640 with 10\% FCS and recombinant human IL-6 (gifts from Dr Steven Gillis, Immunex Co., USA). 7TD1 cells were seeded into 96well flat-bottomed microtitre plates (Nunclon, Denmark) at a density of 1000 cells/well. Supernatants to be tested were added to the cells and incubated for 3 days in a humidified atmosphere. Cells were pulsed with $\left[{ }^{3} \mathrm{H}\right]-\mathrm{TdR} 18500 \mathrm{~Bq}$ for the last $12 \mathrm{~h}$ and were collected using a cell harvester. The incorporation of $\left[{ }^{3} \mathrm{H}\right]-\mathrm{TdR}$ was measured using a FJ-2107 scintillation counter (Xi-an, China).

\section{Results}

IL-6 production induced by LPS: The levels of IL-6 production were determined by measuring the radioactivity of $\left[{ }^{3} \mathrm{H}\right]-\mathrm{TdR}$ incorporation in 7TD1 cells. LPS at $6-12 \mu \mathrm{g} / \mathrm{ml}$ markedly induced IL-6 production from murine spleen cells (Fig. 1).

Inbibition of Tri on IL-6 production from splenocytes: Splenocytes were incubated with LPS and Tri for $48 \mathrm{~h}$. The release of IL- 6 induced by LPS $(12 \mu \mathrm{g} / \mathrm{ml})$ was shown to be significantly reduced by Tri at $0.1-10 \mu \mathrm{mol} / 1$ in a concentration-dependent manner as indicated in Fig. 2.

Time course of IL-6 production: Tri co-cultured with LPS stimulated splenocytes for 24, 36, 48, 60 and $72 \mathrm{~h}$. The data in Fig. 3 shows that at all times tested,

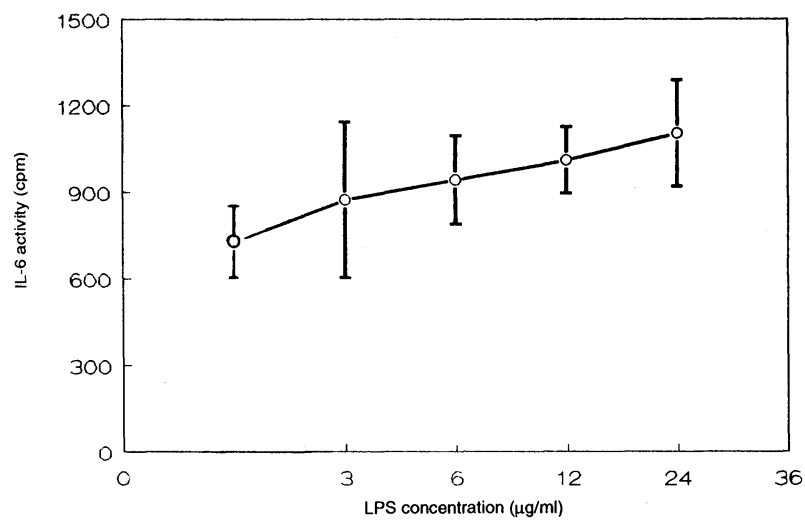

FIG. 1. Effect of lipopolysaccaride (LPS) on the production of interleukin-6 (IL-6) in mouse splenocytes. $x \pm$ S.D., $n=6,{ }^{\star} p<0.05,{ }^{\star \star} p<0.01$ vs control.

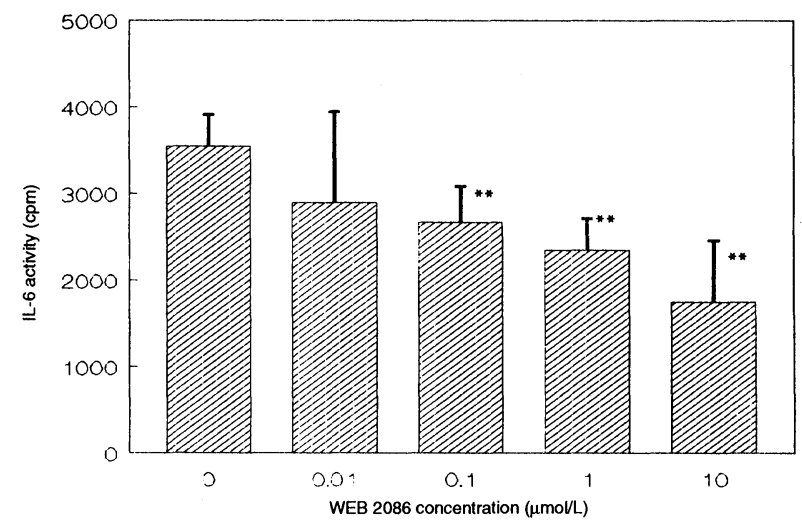

FIG. 2. Inhibitory effects of triazolodiazepine (Tri) on LPS ( $12 \mu \mathrm{g} / \mathrm{ml})$ stimulated IL-6 production in murine splenocytes. $x \pm$ S.D., $n=6,{ }^{\star} p<0.01$ vs control.

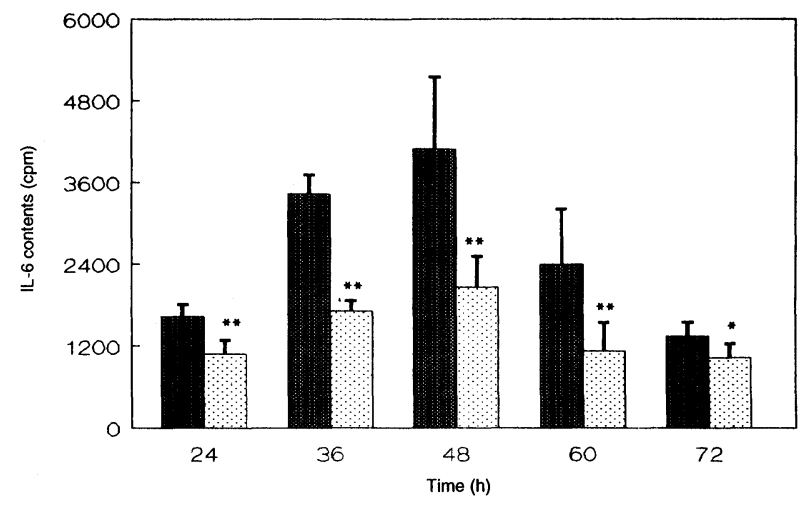

FIG. 3. Time-independent inhibition of Tri $(10 \mu \mathrm{mol} / \mathrm{l})$ on the production of IL-6 in mouse splenocytes. $x \pm$ S.D., $n=6,{ }^{*} p<0.05,{ }^{\star \star} p<0.01$ vs LPS group. L, LPS alone; , LPS+WEB 2086.

Tri $(10 \mu \mathrm{mol})$ elicited strong inhibitory effects on IL6 production in murine spleen cells, suggesting that Tri inhibited IL-6 production in a time-independent manner.

IL-6 production from synovial cells: Rabbit synovial cells were stimulated with IL-1 and TNF for $24 \mathrm{~h}$. The results demonstrated that $\mathrm{IL}-1$ at 10 and $100 \mathrm{U} / \mathrm{ml}$, TNF at 1 and $10 \mathrm{U} / \mathrm{ml}$ both significantly stimulated IL6 release from synovial cells. The inducing effects seemed to be concentration-dependent (Table 1).

Table 1. Effects of tumour necrosis factor (TNF) and interleukin-1 (IL-1) on IL-6 production from cultured rabbit synovial cells. $\mathrm{x} \pm$ S.D., $n=6,{ }^{\star} p<0.05,{ }^{* *} p<0.01$ vs control

\begin{tabular}{lc}
\hline Drugs U/mI & IL-6 activity $(\mathrm{cpm})$ \\
\hline Control & $2081 \pm 328$ \\
$\mathrm{IL}-1$ & \\
1 & $2217 \pm 256$ \\
10 & $2533 \pm 374^{\star}$ \\
100 & $3450 \pm 476^{\star \star}$ \\
TNF & \\
0.1 & $2398 \pm 522$ \\
1 & $2870 \pm 513^{\star \star}$ \\
10 & $4253 \pm 631^{\star \star}$ \\
\hline
\end{tabular}




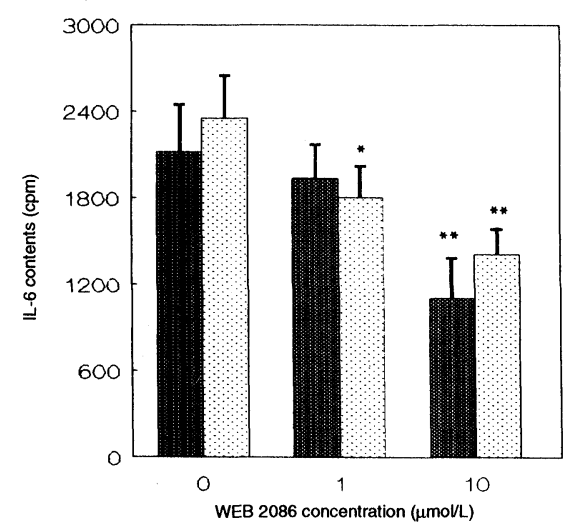

FIG. 4. Inhibitory effects of Tri on the production of IL-6 induced by IL-1 (100 $\mathrm{U} / \mathrm{ml})$ and TNF $(10 \mathrm{U} / \mathrm{ml})$ from rabbit synovial cells. $X \pm$ S.D., $n=6$, ${ }^{\star} p<0.05,{ }^{\star \star} p<0.01$ vs control., IL-1 $(100 \mathrm{U} / \mathrm{ml})$; , TNF $(10 \mathrm{U} / \mathrm{ml})$

Reduction of IL-6 production from synovial cells by Tri: IL-6 release challenged by IL-1 $(100 \mathrm{U} / \mathrm{ml})$ was markedly reduced by Tri $(10 \mu \mathrm{mol} / \mathrm{l})$. Tri also inhibited TNF $(10 \mathrm{U} / \mathrm{ml})$ induced IL-6 production at 1 and $10 \mu \mathrm{mol} / 1$ (Fig. 4).

\section{Discussion}

IL-6 is known to have multiple actions on the growth, differentiation and function of lymphoid and non-lymphoid cells. It has recently been suggested that this cytokine plays a role in the pathogenesis of autoimmune disorders, in which excessive production of IL-6 may lead to abnormal B-cell differentiation and antibody production. ${ }^{7}$ This study demonstrates that LPS significantly induced IL- 6 production from murine spleen cells in vitro. Since splenocyte culture is a mixture of T-cells, B-cells and macrophages, the data here do not provide direct insight into the cellular source of IL-6. It is reported that macrophages, fibroblasts and endothelial cells are the main IL- 6 producing cells, ${ }^{8}$ but we also found that IL- 1 and TNF stimulated IL- 6 production in cultured rabbit synovial cells. IL- 6 release from synovial cells in arthritic DBA/ij mice was reported by Sugita et al. ${ }^{9}$ Elevation of IL-6 levels in sera and paws of autoimmune arthritic animals was also demonstrated. ${ }^{10}$ In previous work it was found that IL-6 stimulated proliferation of synovial cells. ${ }^{5}$ These data suggest that abnormal IL- 6 production may be an important pathological parameter and a contributory factor in the proliferative lesions of arthritic disease.

Tri is a specific PAF antagonist. We found that Tri reduced the production of TNF from murine peritoneal macrophages, IL-1 and colony-stimulating factor from mouse splenocytes. ${ }^{4,11}$ In this study we found that Tri exerted strong inhibitory effects on IL6 production from LPS stimulated murine spleen cells and cultured rabbit synovial cells. We speculate that PAF may play an essential role in the production of these cytokines. PAF is a major inflammatory mediator which may interact with other cytokines such as IL-1, IL-6, CSF and TNF, thereby resulting in an autocatalytic augmentation of the inflammatory response..$^{3,12-14}$ Tri, being able to exhibit strong inhibitory effects on the production of these mediators, may be of great use in anti-inflammatory therapy.

\section{References}

1. Hirano T. Interleukin-6 and its relation to inflammation and disease. Clin Immunol Immunopatbol 1992; 62: s60-s65.

2. Theisen-Popp P, Pape H, Muller-Peddinghaus R. Interleukin-6 (IL-6) in adjuvan arthritis of rat and its pharmacological modulation. Int J Immunopharmacol 1992; 14: $565-571$.

3. Koltai M, Hosford D, Guinot P, Esamu A, Braquet P. Platelet activating factor (PAF), a review of its effects, antagonists and possible future clinical implications (part I). Drugs 1991; 42: 9-29.

4. Ju DW, Zheng QY, Wang HB, Fang J. Inhibitory effects of triazolodiazepine on mouse splenocytes and peritoneal macrophages in vitro. Acta Pharmacol Sin 1994; 15: $65-68$.

5. Ju DW, Zheng QY, Wang HB, Fang J. Effects of leflunomide on cytokine-induced DNA synthesis of rabbit synovial cells in culture. Acta Pharmacol Sin 1994; 15 223-226.

6. Engelberts I, von Asmuth EJU, van der Linden CJ, Buurman WA. The interrelation between TNF, IL-6, and PAF secretion induced by LPS in an in vivo and in vitro murine model. Lymphokine Cytokine Res 1991; 10: 127-131.

7. Hirano T, Matsuda T, Turner M, et al. Excessive production of interleukin 6/B cell stimulating factor- 2 in rheumatoid arthritis. Eur J Immunol 1988; 18: 1797-1801.

8. Aarden LA, De Droot ER, Schaap OL, Lansdorp PM. Production of hybridoma growth factor by human monocytes. Eur J Immunol 1987; 17: 1411-1416.

9. Sugita T, Ueno M, Furukawa O, Murakami T, Takata I, Tosa T. Effect of a novel anti-rheumatic drug, TA-383, on type II collagen-induced arthritis-suppressive effect of TA-383 on interleukin 6 production. Int J Immunopharmacol 1993; 15 515-519.

10. Sugita T, Furukawa $O$, Ueno $M$, Murakami T, Takata I, Tosa T. Enhanced expression of interleukin 6 in rat and murine arthritis models. Int J Immunopharmacol 1992; 15: 469-476.

11. Ju DW, Zheng QY, Wang HB, Wang XF, Fang J. Effect of platelet activating facto antagonist WEB 2086 on the production of TNF from murine peritoneal macrophages. Acta Pharm Sin 1993; 28: 721-727.

12. Braquet P. PAF/cytokine auto-generated feed back networks in microvascula immune injury: consequences in shock, ischemia and graft rejection. JLipid Media 1989; 1: 75-79.

13. Rola Pleszczynski M, Thivierge M, Ganon N, Lacasse C, Stankova J. Differential regulation of cytokine and cytokine receptor genes by $\mathrm{PAF}, \mathrm{LTB}_{4}$ and $\mathrm{PGE}_{2}$.J Lipid Mediat 1993; 6: 175-181.

14. Thivierge $M$, Rola Pleszczynski M. Platelet-activating factor enhances interleukin6 production by alveolar macrophages. J Allergy Clin Immunol 1992; 90: 796-802.

Received 8 November 1994;

accepted in revised form 10 January 1995 


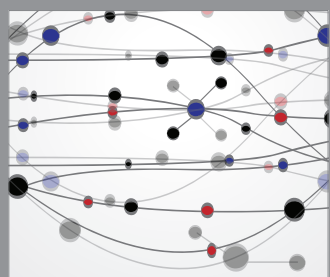

The Scientific World Journal
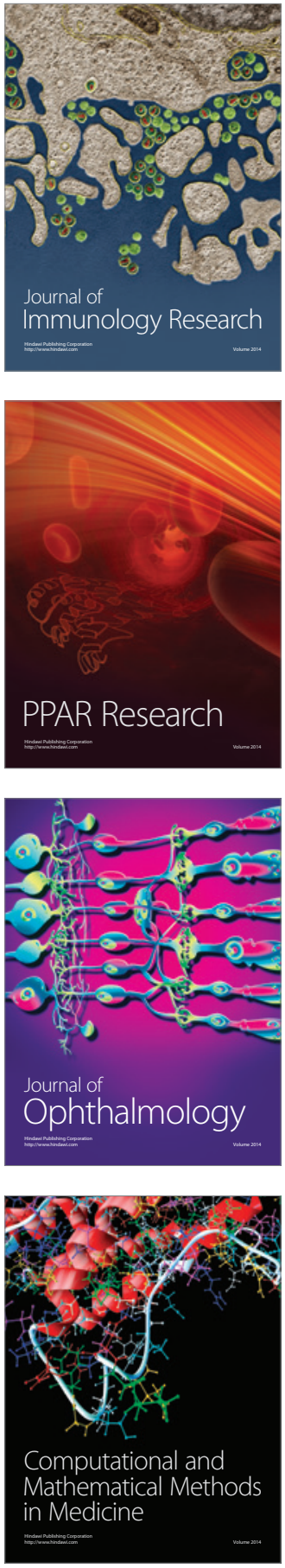

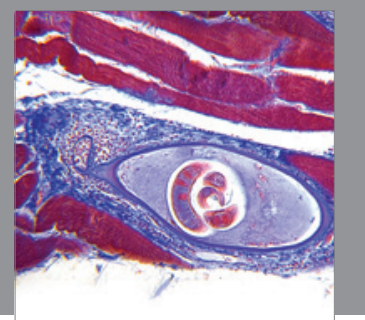

Gastroenterology

Research and Practice
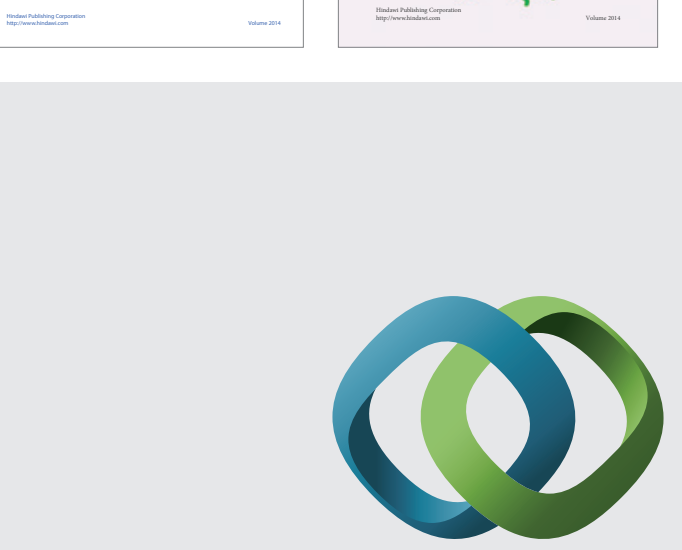

\section{Hindawi}

Submit your manuscripts at

http://www.hindawi.com
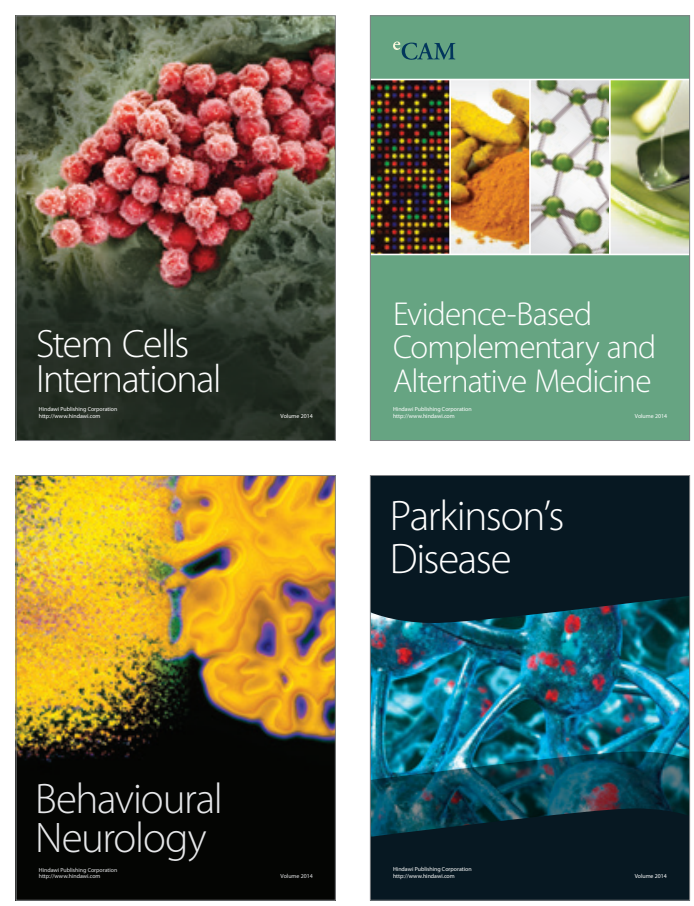

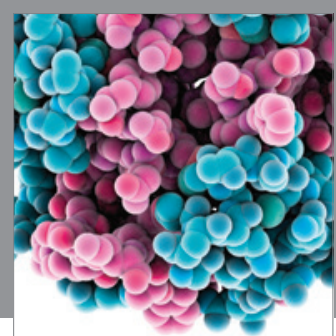

Journal of
Diabetes Research

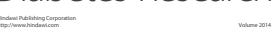

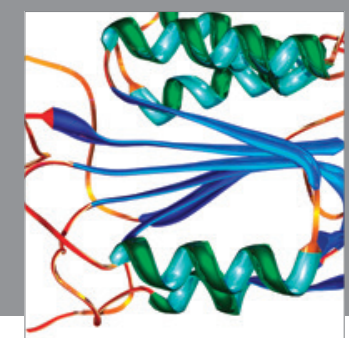

Disease Markers
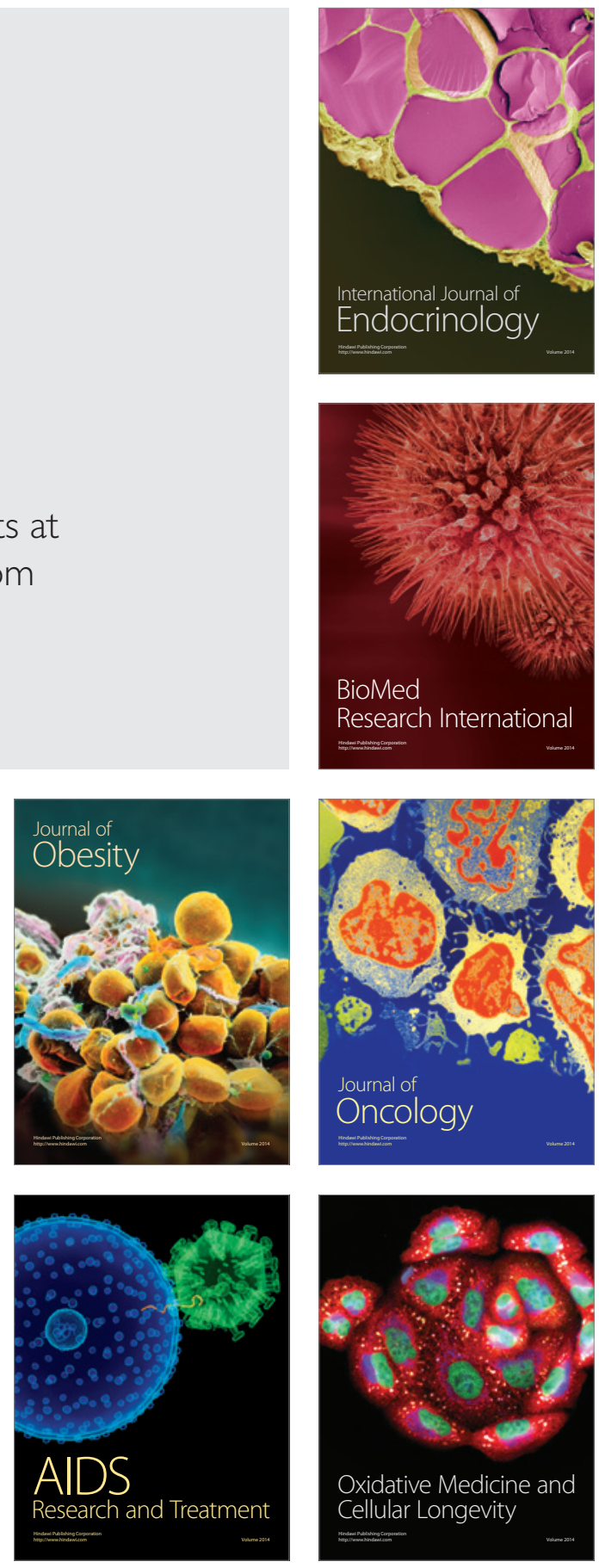